\title{
VALENTINE DE SAINT-POINT, RICCIOTTO CANUDO, F. T. MARINETTI: EROTICISM, VIOLENCE AND FEMINISM FROM PREWAR PARIS TO COLONIAL CAIRO
}

\section{Valentine de Saint-Point, Woman Warrior}

In her "Manifeste de la femme futuriste" (1912) and "Manifeste futuriste de la luxure" (1913), Valentine de Saint-Point ostensibly came to the defense of women against the abuses of futurist misogyny, yet her manifestos have suffered a critical fate similar to that of Marinetti's Mafarka le futuriste, and Valentine has gained a notoriety of her own. ${ }^{1}$ Even her avantgarde practice of abstract choreography and dance before and during the First World War has come to be regarded with suspicion as fascistic, antifeminist and unfeminine. ${ }^{2}$

De Saint-Point is without question one of the more baffling among the futurist women; she is also effectively the first "official" woman futurist, and one of the most original. Her association with futurism was actually rather brief, though significant. She was an extraordinarily independent woman and, as the extended research by the Tunisian feminist critic and historian Fawzia Zouari has revealed, she lived a complex and highly unusual life. ${ }^{3}$ Most critics, however, have identified Valentine de SaintPoint solely with her futurist manifestos, ignoring or dismissing the rest of her life and work. Even more paradoxically, they have made Valentine de Saint-Point herself the principal representative of women's participation in futurism, and of all the negative, anti-feminist and fascistic traits that are supposed to have characterized it as a whole.

To be sure the two manifestos are shocking and filled with violent pronouncements and images. Yet to view them as "representative" or symptomatic in this way, and especially as proto-fascist, means to simplify excessively and to take them out of their specific historical and cultural context. The powerful language of the manifestos has contributed to its a-historical reading. Indeed, the fact that her texts continue to be so topical and controversial is indicative of the way in which Valentine anticipated many of the most contested questions of contemporary feminist theory and criticism while claiming a space for women within the avant-garde. 
Contrary to what most critics maintain in the light of her distant relation to Alphonse de Lamartine and her impressive list of names, ${ }^{4}$ Valentine de Saint-Point (also known as Anne-Jeanne-Valentine-Marianne Desglans de Cessiat-Vercell) did not come from a privileged aristocratic background. Her aristocratic names, including de Saint-Point, were of her own devising, with only tenuous anagraphical foundations and legitimacy. Born Anna Jean Valentine Vercell in 1875 in Lyon, she was the daughter of an insurance agent who died when she was eight, and of a provincial middle-class widow, Alice Vercell. Alice, who had been born out of wedlock, was a very strict mother. She had Valentine educated at home by a tutor. Alice's mother (a seamstress) had been the mistress of a nephew of the poet Lamartine, Emmanuel de Cessiat, who married her only in extremis.

Yet Valentine's self-naming was not simply a way of acquiring-however fictionally-higher social status and prestige. Like Rawhiyya Noureddine (the name she chose when she converted to Islam), 5 her names reveal instead her disregard for the conventions of bourgeois identity and gender, and her life-long propensity for self-fashioning and nomadism. Valentine's transformative, restless and multiple approach to her identity resembles the nomadic subjectivity later theorized by Rosi Braidotti. 6 For Braidotti, the nomadic subject is marked by non-adherence to rules, roles, and prescribed models of behaviour. Nomadic subjectivity allows for "disengagement and disidentification from the socio-symbolic institution of femininity" (Metamorphoses 40).

One of the ways in which Valentine disengaged herself from the institution of femininity in early twentieth-century France was by forging an imaginary and enpowering connection with Lamartine. From childhood, encouraged by the maternal grandmother, Valentine had developed a veritable passion for Lamartine, with whom she identified profoundly. Saint-Point is the name of the mountain village where Lamartine was buried in 1869. Through her cult of Lamartine, Valentine seems to have compensated for the lack of a father, creating a powerful masculine model for herself. As we shall see, she also cultivated a spectacular, even shocking femininity. Lamartine's predilection for Italy and the Orient (particularly Egypt and Morocco) especially influenced Valentine, as did Lamartine's mysticism, his utopian political fervour, and his intense erotic life. Lamartine expressed great admiration for what he called "the genius" of the Prophet Mohammed and for the creation of Islam and the Muslim religion (276-277). This admiration too was to have profound repercussions on Valentine.

Against the hopes of her mother and grandmother, Valentine married a petty-bourgeois lycée teacher, Florian Perrenot. They settled down to a 
dull provincial life in the district of the Jura, but Valentine soon took a lover, Charles Dumont, a radical socialist and a teacher of philosophy. Encouraged by Valentine, he moved on to politics and became the Jura representative to the parliament in 1898. His apoplectic fit left Valentine a widow, free to discard the Perrenot name and move to Paris, where she married Dumont on the first day of the new century. The spectacle of politics in the French Third Republic, however, and the discovery of the life of dreary compromises led by her husband and his colleagues increasingly nauseated her. In the Paris of the belle époque (where Marinetti was also living off and on at the time) Valentine began leading an electrifying life, first turning herself not into a typical politician's wife but rather into a flaneuse. She was thus a rare female counterpart of the traditionally male figure of the flaneur, the man of the crowd idealized by Baudelaire. The couple was divorced in 1904 and there was an amicable (though unofficial) settlement. ${ }^{7}$ (Dumont went on to become a senator, and was minister in several cabinets until his death in 1939).

Although a notable group of famously liberated and unconventional women lived in Paris at the time, including Colette, Rachilde, Sarah Bernhardt, and the expatriates Natalie Barney, Edith Wharton and Gertrude Stein, the prevalent ethos among French women and in French society in general was the bourgeois feminine ideal that regarded family and motherhood as the only appropriate mission for women. Even Colette suffered deeply from this discriminatory and sacrificial ethos, and all the earnings from her writings were pocketed by her husband Willy, who pretended to be the sole author of the Claudine novels until Rachilde discovered the truth. Egalitarian legal reforms continued to assume the primacy of women's maternal role, as did the French feminist movement. Suffragism was never popular (women in France obtained the vote only after World War Two). ${ }^{8}$ French women were generally educated to believe in a sacrificial ethics of femininity. Woman was to devote herself entirely to her husband and children. She was not supposed to feel sexual desire, but rather feminine "love." Feminine love was to be tender, affectionate, and compliant. To reject this bourgeois feminine ideal, Valentine de SaintPoint, while pointedly refusing to become a wife and mother, constructed the image of a strong woman that took the notion of maternity and of the female body to radical, provocative extremes. She was thus equally unacceptable to the conservatives and to the moderate, reformist feminists.

Valentine published her first volume of poetry, Poèmes de la mer et du soleil, in 1905. One of Valentine's poems appeared in 1908 in Marinetti's Poesia, which later published several other poems by her. Valentine's flam- 
boyant style of dressing in an orientalist fashion (especially after a visit to Morocco, following Lamartine's footsteps), her unusually colourful and immense hats and cloaks eventually earned her the nickname of "la Muse pourpre," a reference to her preference for red and purple.

In her penchant for feminine masquerade and orientalist ornamentation, Valentine seems to have been an example of "sartorial female fetishism." From the start, Valentine's display of feminine luxe and her propensity for masquerade and veiling entailed a strong element of daring, "masculine" volition. It thus had little in common with Joan Riviere's notion-theorized in her classic 1929 essay-that womanliness is often nothing but a masquerade, a strategy. According to Riviere, woman, when confronted with a men's world, wears womanliness as a mask, "both to hide the possession of masculinity and to avert the reprisals expected if she was found to possess it" (42). Valentine instead created and boldly projected the image of a strong, "masculine" femininity that was neither submissive nor reducible to the paranoid stereotype of the femme fatale despised by the futurists. Indeed, it was precisely this aura that first attracted Marinetti, who felt for a time that Valentine could embody the new futurist woman. However, Valentine's vision of the female body and the cognitive and spiritual role that she attributed to eroticism eventually clashed with Marinetti's more athletic, casual and materialist notion of sexuality.

For Valentine luxe was essentially an expression of female luxure, a way of eroticizing the body and the objects in contact with it. Valentine's theory of desire or luxure implied, as we shall see, a liberation of all forms of desire, unbound from the bourgeois (as well as fascist) imperatives of reproduction and the restrictions of the patriarchal family, as well as from the symbolic rule of the father that still informed a large section of the avant-garde. The worrisome, even dangerously evil connection between female luxury (both sartorial and cosmetic) and a wasteful, self-serving female lust (rather than procreative sexuality) celebrated by Baudelaire was re-appropriated by Valentine as an expression of female power and eroticism. In the manifesto "Contro il lusso femminile" (1920), written in the postwar climate of male paranoia and resentment against emancipated women, Marinetti would later criticize female vanity and women's pleasurable, sensual display of elegance as selfish and emasculating, calling it a morbid negation of "true desire" (Teoria 547). ${ }^{10}$ Female eroticism and any form of wasteful feminine ornamentation were anathema to the fascist regime, which generally encouraged moralism in sexual matters for women and sought to inculcate modesty along with parsimony and family values. Shortly after her entrance into Parisian society, Mucha painted 
Valentine's portrait and Rodin used her as a model for several of his sculptures. (They and Marinetti were rumored to be her lovers). Soon afterwards, she began to paint and sculpt herself, showing her works (none of which appear to be extant) at the Salons des Indépendants. Turning her gaze back on the master for whom she modelled, in 1913 she wrote an essay on Rodin and lectured on him, praising him for replacing the classical anthropomorphic and mimetic ideal with a more "architectural," abstract approach. ${ }^{11}$ Abstraction, and the rejection of mimesis, were at the same time becoming essential elements of her new theory of choreography.

Valentine soon had her own atelier that also functioned as a salon, where evenings of music, poetry, dance and theatre performances were held. She befriended Vivian du Mas and began attending theosophical meetings and spiritualist soirées, a common activity among Parisian intellectuals and even avant-garde writers and artists. At one of these evenings she met the man who was to become her "soul mate" until the First World War, Ricciotto Canudo. Canudo, whose complex role as cultural mediator between Italy and France is still scarcely understood, is often incorrectly assumed to have been a fanatical French nationalist, and Valentine's association with him is sometimes used as evidence of her own reactionary leanings. ${ }^{12}$

Canudo was a southern Italian (from a small town near Bari) who studied literature and oriental languages and religions in Florence and Rome, where he moved in literary and theosophical circles. He helped Valentine improve her spoken Italian (like her adored Lamartine, Valentine was a great Italophile). In 1910, Canudo invited her along with Apollinaire and others to join him in Brussels for a lecture series on Italian literature. Apollinaire lectured on Aretino. Valentine's lecture, later published as an essay, was entitled "La femme dans la littérature" and was the first in a series of talks that testify to her idiosyncratic feminism and deep interest in the question of women's creativity and their relationship to the institutions of literature, theatre and the arts. ${ }^{13}$

In her knowledgeable overview of woman as icon in Italian literature from Dante on, and of the literary production by Italian women, Valentine perceptively points to the restrictions that Italian culture and society still placed on women even in the early twentieth century, in contrast to the relatively freer intellectual exchange and socialization allowed in France, especially after the reinstatement of divorce. She refers explicitly to Sibilla Aleramo's Una donna as well as to the feminist novels by Bruno Sperani, Marchesa Colombi, Regina di Luanto and others, remarking that in Italy women writers were still in the position of having to denounce and expose 
in their works the psychological and ideological as well as institutional oppression of women, whose bodies and minds were not yet free. In contrast, Valentine argues, women in France were freer to live according to their own desires. Their literature, therefore, was less concerned with the kind of social issues that make Una donna a powerful feminist pamphlet than with the question of how to create a specifically feminine esthetics and a feminine voice.

Valentine acknowledges the stature and greatness of Matilde Serao and Grazia Deledda, but observes not only that they are decidedly anti-feminist, but that they have embraced a masculine perspective and have not contributed to reveal anything new and genuine about female psychology. Their writing does not reveal their sex, Valentine asserts. Valentine cites on the other hand two poets as examples of an Italian feminine avant-garde in this sense: Amalia Guglielminetti and Térésah. She quotes extensively from Guglielminetti's Seduzioni, a book that she calls unsentimental, violently sensual and daring, and a model for all women poets. Térésah's work on the other hand, from which she quotes extensively in her own translation into French, is in her view more abstract, imaginative, ironic and almost phantasmagoric. (Térésah was also a favorite of Palazzeschi's at the time). Valentine's critical assessment is of course a reflection of her poetic taste and of tendencies in her own writing, though recent appreciations of Guglielminetti show that Valentine's evaluation was perhaps less subjective and more farsightedly feminist than it might have previously appeared.14

Like Marinetti's early poems, Valentine's poems and prose poems, including Poèmes d'orgueil (1908), La Guerre (1912) and La Soif et le mirage (1912), belong in esthetic and formal terms to the mode of late symbolism. They are, however, notable in terms of images and themes, a central one being female sexuality and desire or "lust," to which she attributes a potentially disruptive and violent power. Valentine describes desire in extreme terms, as that which can never be fulfilled, an endless, unsatisfiable drive: "Le Désir / Qui crée les désirs / Insatiablement . . Nulle paix, ni détente, ni satisfaction" (La Soif 19). Desire is thus a "force," a potentially devastating energy, and is connected to fantasies of both violence and war-the ultimate discharge of libidinal energies. Violence and war are themes that Valentine placed at the centre of her two futurist manifestos of 1912 and 1913.

Classic futurist topoi such as the train, the automobile, and the airplane that appear in her poetry are regarded from a woman's point of view. Valentine celebrates the new, accelerated, and compressed perception of time and space and the different kinds of desire and imagination that are generated in her by the experience of speed and flying. It is therefore not 
surprising that Marinetti should find Valentine interesting as a poet (a review of Poèmes d'orgueil appeared in Poesia in June 1908) and attempt to enlist her in the futurist ranks.

The female subject depicted or speaking in Valentine's texts, either directly or indirectly, is the antithesis of the inert, tender, passive and compliant bourgeois female. Her poetry is saturated with sadistic and masochistic fantasies. Ironically, Valentine's notion of desire is reminiscent (or perhaps a precursor) of Freud's and of those of later Freudian theorists, including Klaus Theweleit, invoked to chastise Valentine's supposedly fascistic perversion and deviant femininity.

The most important intellectual influence on Valentine, however, was Nietzsche, who had died in 1900. A two-volume French translation of Der Wille zur Macht was published in 1903, but Valentine was already familiar with Nietzsche's radical thought from the days of her affair with Dumont. In "Preparatory Human Beings," a famous fragment of The Gay Science (Die Fröliche Wissenschaft,1887), Nietzsche had succinctly formulated his ethics of violence: "I welcome all signs that a more virile, warlike age is about to begin ... the age that will carry heroism into the search for knowledge and that will wage wars for the sake of ideas and their consequences" (228). It is a motif that deeply resonates in Valentine's poetry and prose. Valentine saw herself as one of Nietzsche's preparatory human beings and wholly embraced his ethics of regenerative violence even as she rejected Nietzsche's vision of woman's sexuality. For Nietzsche, women's sexuality resided entirely in the desire to be possessed ("Woman wants to be taken and accepted as a possession, wants to be absorbed into the concept of possession, possessed" The Gay Science 319). For Valentine, however, this desire represents only one side of female sexuality, or a possible gender position for woman as well as man.

Between 1906 and 1910, Valentine published a series of Nietzscheinspired novels, including Un amour, Un inceste and Une mort, which formed the Trilogie de l'amour et de la mort. She also published the novel Une fermme et le désir (1910) and L'Orbe pâle, a book of prose poems (1911). These novels and prose poems have a distinctly Dannunzian flavor, but are written from a decidedly female perspective with strong (if idiosyncratic) feminist implications. The latter two works in particular delineate the phantasmatic image of a phallic woman, with a sword in her hand, that still has the power to scandalize. ${ }^{15}$ For although Valentine, like Freud, asserts the power of the libido in both women and men, her woman oversteps the very limits of "womanhood" articulated first by Nietzsche and later by Freud in his theory of the female as always "castrated." 
In her desire to counter the turn-of-the-century misogynist scenario of sexual difference (that influenced deeply both Nietzsche and Freud) and the dogma of the inferiority and passivity of woman, Valentine polemically sees the symbolic phallus as a sign of power and strength that can be woman's as well as man's. Valentine's imagination thus still envisions a phallic symbolic economy, but in fantasizing a powerful phallic woman Valentine steps outside its traditional male boundaries. For while for Freud the phallic desire, that he called "penis envy" (an expression that first appeared in a 1908 essay), ${ }^{16}$ is a phase of the little girl's immature sexuality that in the mature woman is transformed into the desire to have a child and to be sexually possessed by man, Valentine's powerful woman is simultaneously both phallic and a mother, both "masculine" and "feminine." Valentine's phallic woman embodies a fantasized creative potency.

In creating the image of an ideal, superior and phallic woman (a kind of woman warrior) Valentine is not immune to the suggestions of the Darwinian and Lamarckian evolutionist scenario that deeply influenced Nietzsche and Marinetti. Yet her view of woman effectively reverses both Darwin's and Nietzsche's. Nietzsche had written: "This is how I want man and woman: the one a good warrior, the other a good mother, but both good dancers with the head and legs" (Thus Spoke Zarathustra III, 23). Valentine, instead, set out to show that a woman could be as good a warrior/dancer as man. Valentine's fantasy of female virility does not subtend a proto-fascist tendency to identify with the male leader and his violence while simultaneously construing femininity passively, through the optic of male domination and female subjection. On the contrary, Valentine's ideas and narratives constitute a set of liberatory fantasies, the imaginary staging of "another woman." They are formulated precisely in opposition to the dominant notion of the feminine as exclusively and fatefully inert and inferior.

Before becoming a performer and going on the stage as a dancer, Valentine also wrote for and about the theatre, attempting to create a new tragic "Théâtre de la Femme," and publishing Le Déchu, a drama performed in 1909 at the Théâtre des Arts. Valentine observed that although woman was everywhere in the theatre, the privileged subject of endless plays, the actual individuality and complexity of women remained invisible. She felt that most authors (D'Annunzio in particular) relied on stereotypes, endlessly rehearsing the male-created opposition between the selfsacrificial woman and the destructive femme fatale. Even Ibsen's women seemed types rather than complex individuals ("Le Théâtre de la femme," Manifeste 39-40). L'Âme impériale, ou l'agonie de Messaline (written around 1907 , but published only in 1929) was an attempt to write a neoclassical 
modernist drama in the Dannunzian vein, but from a female perspective. In its linking of female sexuality and seductiveness with political power and the excitability of the crowd, it resembles D'Annunzio's 1905 incendiary tragedy La Nave (which Canudo translated into French) except that in D’Annunzio's tragedy the heroine (Basiliola) commits suicide, while in Valentine's drama it is Messaline (the incitatrice) who triumphs. ${ }^{17}$

Valentine's passion for Nietzsche was linked to the way in which Nietzsche, despite his anti-woman prejudices, brought the body back into philosophy. Valentine's vision of her own body is both heterosexual and bisexual. Unlike other women rebels of the belle époque, who chose the lesbian as the symbol of the new woman, Valentine de Saint-Point's woman is the "strong" (and therefore "perverse") heterosexual woman, whose sexuality is coextensive with her creativity. ${ }^{18}$ In her union with Canudo (from whom she declined to have a child) she pursued the ideal of the creative couple that Sibilla Aleramo also theorized in a different way. (A version of this ideal was embodied at the time by Sonia and Robert Delaunay, among others).

In her trilogy of novels, Valentine outlined the figure of a mother-son incestuous couple (inspired by Nietzsche's "mother in the son"), where the figure of the husband and father is effectively eliminated from the sexual and creative process. In an exact reversal of Mafarka's paradigm of womanless paternity (Valentine's third and final novel of the trilogy appeared in La Nouvelle Revue between December 1909 and March 1910) it is the mother who effectively "creates" a son without a father, though the son finally fails to incarnate the mother's heroic desire by betraying the incestuous bond after the mother's death.

\section{Valentine and Canudo}

Although their backgrounds were quite different, Valentine and Canudo shared a deeply utopian ethos and an esthetic idealism that was typical of some prewar intellectual circles in Paris. Canudo, like D'Annunzio and Marinetti, was a versatile, "total" intellectual, open to all forms of esthetic expression and spectacle, though he lacked their cynicism and talent for self-promotion. Working as a critic and then as a translator, Canudo had moved to Paris in 1901, where he lived a precarious bohemian existence. He became an associate of Sofficis, met (among others) Joyce, Marinetti, Apollinaire, Marie Laurencin, and Edgar Varèse, and began writing in French magazines about Italian theatre and music, as well as lecturing and composing his own works for the theatre. One of his lectures, which he published as part of the collection L'Âme de Dante, was "Psychologie 
Dantesque de la Luxure" and appears to have influenced Valentine's notion of luxure as a powerful spiritual force. During one of his Dante courses in 1910, he presented the new film adaptation of Dante's Inferno by Francesco Bertolini and Adolfo Padovan, a work that was pivotal in the literary and artistic legitimation of the new medium, usually considered mere entertainment for the masses rather than an art form.

Before focusing his attention on cinema, however, Canudo began thinking about the idea of a cosmopolitan Mediterranean culture-especially music and theatre-and, like Valentine, became particularly interested in the notion of a modern Mediterranean revival of the Greek open-air theatre tradition. The new theatre would combine music, images, dance, and drama in a total synthetic and cinematic spectacle. It was meant to be a Mediterranean answer to Wagner, similar to D'Annunzio's theatre of Albano as described in Il Fuoco and other French neo-Greek theatre projects at the time. Along with a group of other enthusiasts, Canudo started a society for this kind of theatre to be performed at Orage and wrote several works for it, including the symphonic tragedy Le Délire de Clytemnestre with music by Varèse.

Canudo also wrote novels, among which La Ville sans Chef (1910) a work that provides interesting evidence of Canudo's and Valentine's intellectual position vis-à-vis both Marinetti and D'Annunzio. The novel, which expresses in symbolic form many of the anxieties related to the new mass society and the urban and industrial crowds described in Gustave Le Bon's work, is the apocalyptic story of an anarchist, Vincent. Vincent is an idealist who believes in the possibility of creating a community made of free-thinking individuals without oppression, political demagogues, or leaders, but becomes alienated and disenchanted, finally learning to rely only on himself and to believe only in the creative individual (a position not unlike that of Boccioni's). Canudo shared with Marinetti and the futurists a profound interest in anarchism, but unlike Marinetti he believed in the need for a creative dialectic of tradition and innovation. Also unlike Marinetti, who sought to devalue sexuality at least symbolically, Canudo was interested in the fundamental intellectual and psychological function of human sexuality. Alluding to Nietzsche, he wrote: "La sexualité monte au faite de l'intelligence" (L'Ame 66). It was a view that he shared with both Valentine and D'Annunzio. ${ }^{19}$

In 1911, Canudo had joined Méditerranée, a monthly review of politics and literature "for a united federation of the Latin peoples," and in October of the same year he published his seminal, first essay on film theory, "La Naissance d'un sixième art." Later, he called cinema the seventh, 
rather than the sixth art, for cinema represented the fusion of three arts of space - painting, architecture and dance-with three arts of time-music, theatre and literature ("Reflections on the Seventh Art" 296). In her own work, Valentine soon became aware of the need to go beyond traditionally-staged tragedy and to create a more cinematic kind of spectacle, her Métachorie. In 1912, Canudo founded with Mme Zekowaia and others the journal Montjoie! of which he became the full-time editor in chief from 1913 to 1914. Although subtitled "Organe de l'Impérialisme artistique français," Montjoie! was essentially cosmopolitan in its approach and, according to the futurist painter Gino Severini, "even too open to everyone" (127). It published contributions by, among others, Léger, Stravinsky, Gordon Craig, Apollinaire, Max Jacob, Blaise Cendras, Duchamp, Goncharova, and the Delaunays, but also writings by right-wing traditionalists such as Henri Clouard. Despite its nationalist pride and its ideas about cultural imperialism, the journal expressed dislike for L'Action Française (in the sixth issue of 1913 Vivian du Mas published an attack against Barrès) and placed itself rather on the "gauche libérale." 20 Canudo, however, was against political action by artists and writers, and pursued instead the ideal of the independence of art. Ironically, like many young men and women of his generation in Europe, he was soon to be captivated by the myth of redemptive violence, one of the factors that led to interventionist idealism and contributed to World War One, of which, as we shall see, he became one of the most celebrated heroes and poets.

In 1914, Montjoie! launched its own movement, "Cerebrism." The "Manifeste de l'art cérébriste" was published in Le Figaro on 9 February. Cerebrism was a kind of esthetic and avant-garde mystical utopianism based on the notion that all avant-garde artists should be able to overcome their differences (Valentine had distanced herself from futurism by then) and cooperate in forging a new polyphonic artistic soul for the world. Sensuality and intelligence, but not sentimentalism and emotion, were to be the essence of cerebrism.

De Saint-Point's new dance, the "Métachorie" or "dance idéiste" was the embodiment in the theatre of the cerebrist credo that she contributed to create, giving it a theosophic slant. Neither mimetic nor anecdotal, Métachorie was designed, as we shall see, as an abstract form of dance, a stimulant for the intelligence and the imagination. Métachorie was envisioned as the equivalent in dance of cinema's kinetic essence. Canudo conceived of cinema as a synthetic, anti-mimetic fusion of the spatial and the temporal dimensions; evocation, not imitation was to be the goal of filmic expression. Canudo's theories were an important influence on avant-garde 
European film-makers. He perceived cinema as a kind of visual symphony, a writing done with light and shadow, emphasizing the abstract visual aspect of the filmic image as well as the ability of cinema to defamiliarize and valorize details and objects, especially, through the close-up, the human face and other parts of the body and of physical movement. The point of the close-up was to exhibit the illusory quality of the familiar human face by making it strange and mysterious, paradoxically and poerically obscuring, hiding or disfiguring its familiar appearance. Through the cinema, the human perception of the body could lose its habitual, hackneyed predictability and become more complex and surprisingly revealing. Valentine's Métachorie, in which she often used the veil to obscure the face, had a similar goal.

The war put an end to Canudo's editorial and critical activities for a while and, eventually, his relationship with Valentine. He and Blaise Cendras signed an appeal to all foreign friends of France to join in aiding the French. Canudo himself, who was not a French citizen, asked and was granted permission to join the Foreign Legion in a special regiment of volunteers organized and led by Peppino Garibaldi (a grandson of Giuseppe Garibaldi). This is not a mere historical detail, but rather an eloquent sign of the cross-national idealism that was at the root of Canudo's and others' desire to fight. Although the violence of World War One and the frustration that the war eventually generated were at the root of Mussolini' formation (and of what was to become the opportunism and ruthlessness of the fascist movement) to associate Canudo with fascism on the basis of his enthusiasm for Latin culture and his willingness to fight in what seemed a heroic war seems excessive and unwarrented. The myth of redemptive violence was as powerful on the right as it was on the left, and was hardly connected exclusively with fascism. However, it was precisely the spectacle of the reality of violence in the war (rather than the fantasy of violence, which could indeed be liberating) that led Valentine to revise entirely her pro-war position, while Canudo became a war hero and entirely committed to the heroic ethos of war for the duration of the conflict.

Canudo was decorated in 1915 for fighting valiantly in the Argonne as captain of a detachment of Italian volunteers. He was subsequently wounded and while he recovered in a hospital in Nice he wrote the first of his many war poems, which were well received and were awarded the Prix Montyon in 1917. In May of 1915, he received the news that Italy had joined the war and that the Garibaldi legion had consequently been dissolved. In Serbia, with the rank of Captain of the Italian army, he asked and obtained permission to fight with the French. In September 1915, he 
embarked with the First Zouave regiment for the Dardanelles. He was wounded during the devastating December retreat, but refused to be evacuated. Before being reassigned to the Italian army in the Orient, he was stationed in Salonika, where during his stay in the military hospital he founded a new journal of art and literature, Ça Ira. In August of the same year, he visited Valentine in Barcelona before going back to the Greek front. In November, he received a silver medal for having rescued another captain, wounded during a reconnaissance beyond the enemy lines on the hills west of Monastir. Canudo fought valiantly for the rest of the war, was wounded and decorated again.

Canudo became a kind of wartime legend in his own lifetime, with performances about his life staged in Parisian theatres and war sites named after him. His relationship with Valentine ended during the war. In 1920 he met and later married a young professor of French, Jeanne Benoite Janin, who became Valentine's best friend and companion after Canudo's death.

After the war, until his death from malaria in 1923, Canudo devoted himself almost entirely to cinema. With Abel Gance, Germaine Dulac, and Jeanne Janin, he started a club for friends of the seventh art, writing film criticism and promoting film as an art throughout Europe, although he never abandoned the cause of "Latin culture" and was active in the "Union of the Mediterranean races of Europe, America, Asia and Africa." Canudo's concept of "race," however, was not ethnic or eugenic, but cultural.

\section{Marinetti and Sorel: the Myth of Violence}

While after 1914 Canudo (like Marinetti) never explicitly questioned the heroism of violence and war, Valentine, who was fascinated by the myth of redemptive violence and by the futurists' belligerant language, by 1917 entirely rejected her earlier views. In order to understand how Valentine's encounter with futurism came about and the role that the myth of violence played in that encounter, it is important to understand Marinetti's position in Paris at the time, and his own particular take on the destructiveness of female lust.

When Valentine de Saint-Point wrote her first belligerant futurist manifesto in 1912, futurism had already produced a significant body of work and Marinetti was well-known and even notorious in Paris. Marinetti, who spoke, wrote, and even dreamt in French at the time, had published two collections of symbolist poetry (La conquête des étoiles and Destruction) and the novel Mafarka le futuriste. The work which most contributed, along with the "Founding and Manifesto of Futurism," to make 
his reputation in France, however, was the play Le Roi Bombance, performed in Paris at the Théâtre de l'Oeuvre in 1909, shortly after the publication of the "Founding and Manifesto" in Le Figaro.

The protagonist of the play is "L'Idiot": the unheeded poet who, in contrast to the grossly materialist concerns of the politicians, hungers for the absolute and eventually dies from disgust and disillusionment. The work was a deliberate attempt to outrage, to offend, and to scandalize. It included a riot during which a mob lead by a socialist agitator storms and overtakes the royal castle, proceeding to devour and then vomit the body of the King.

The press called the piece barbaric and anti-French, and there was intense speculation as to the "real" identity of some of the characters, in whom some recognized allusions to actual socialist and anarchist agitators of the time. Marinetti was delighted by this reaction. ${ }^{21}$

In 1906, Georges Sorel's articles had begun appearing in Mouvement Socialiste and were eventually collected in book form under the title Reflexions sur la violence in 1908. For Marinetti and many others it was a revelation. Sorel provided a model for a form of modern heroism that could replace the obsolete and powerless romanticism of "L' Idiot." Like Marinetti, and like Valentine, Sorel had grown disenchanted with the demagoguery of French socialism, increasingly caught up in the seductions of parliamentary politics. Beginning to look elsewhere for an agent of regeneration, he developed the myth of heroic and aggressive action by a group of men bound together by fervent solidarity and motivated by a passionate confidence in the possibility of total change.

The exhilarating possibilities of this ethics of action, heroic sublimity and tribalist solidarity were at the core of the futurist movement and contributed to give it its initial impetus.22 The futurist exaltation of violence (and also Valentine's own particular version of it) must be seen in the context of this passionate and rather idealistic and utopian ethic. Others were interested in the notion of violence elaborated by Sorel (Lenin for example, and certainly Mussolini), but had more practical or instrumental visions of its possible uses. In creating futurism, on the other hand, Marinetti embraced the Sorelian ethic of a group living in the midst of a continuous crisis and anticipating a future of radical transformation. Women, however, were initially excluded from the revolutionary group, which defined itself as essentially masculine and misogynist, thus effectively perpetuating the mentality of bourgeois patriarchy (as well as romantic and symbolist stereotypes).

In the first act of Le Roi Bombance, "L'Idiot" inveighs against the body of woman, which in his view is always "fatal" to man, and women are 
expelled from the kingdom from the outset; they cannot easily be "digested," in fact, due to their insatiable and uncontrollable lust (166-167). As far back as La Conquête des étoiles, the feminine principle in Marinetti's work is negative and opposed to the positive masculine principle, alone capable of reaching the superior ideal symbolized by the stars. In the hallucinatory symbolist language of Marinetti's poems, as in so many other literary texts of that period, female sexuality is repeatedly associated with abjection and destruction, and at the same time it is the object of extended sado-masochistic fantasies often linked to the image-both dreaded and desired-of engulfment or of the bad and the good mother. ${ }^{23}$ "The Founding and Manifesto" of futurism, with its outspoken "mépris de la femme" did not substantially alter this vision of woman and female sexuality.

It was only through Valentine de Saint-Point that Marinetti's awareness of the potential interest of women for futurism and, viceversa, of the ways in which futurism could benefit from launching different cultural and political models for women as well as for men, turned into something like a strategy.

\section{Valentine, Futurism and Luxure}

It was in opposition to Marinetti's expressions of misogyny, which had migrated seemingly unaltered into the futurist works, and by launching a defence of female lust, that Valentine de Saint-Point entered the futurist arena. On the occasion of the 1912 exhibition of futurist painting in Paris, Marinetti, Boccioni, Severini and other futurists had been invited to Valentine's atelier for an evening of performance. "Le Vendeur de soleil" by Rachilde, who was in the audience, was performed, but Marinetti also declaimed one of Valentine's poems, "Hymne au soleil." A second evening of performance took place at Valentine's atelier in June, with music by Ravel, Satie and Debussy, dances by Trouhanova, and a performance of Villier de l'Isle Adam's La Révolte.

Impressed by Valentine, who had publicly declared her agreement with futurist principles but vehemently disputed the futurist devaluation of woman, Marinetti invited her to become the first futurist woman. In her letter of adhesion, Valentine claimed to have in her life and work foreshadowed futurism, but she (like Canudo) expressed disagreement with the futurist iconoclastic rage: past masterpieces should not be sacrificed to the new (Manifeste 9-10).

In March, between the two performance evenings, she wrote her "Manifeste de la femme futuriste," which was published in June after she declaimed it in Brussels at the Galerie Giroux on the 3rd, in conjunction 
with the traveling exhibition of futurist painting, and in Paris at the salle Gaveau on the 27th. Both events were advertised and animated by the futurists with their usual flair for controversy and noisy publicity. The Paris reading and debate were heated and members of the audience were so scandalized that the evening ended in chaos. Valentine herself was immediately branded as immoral and even homosexual by some. ${ }^{24}$

Her notoriety reached its peak when she attempted to clarify her ideas (which she felt had been distorted and misinterpreted by journalists) in the second manifesto, the one on lust, dated 11 January 1913. The liberatory sexual message was immediately picked up by Lacerba's Italo Tavolato-a futurist and one of the few open homosexuals at the time-who published his own "Glossa sopra il manifesto futurista della lussuria" on 13 March 1913. Tavolato read Valentine's manifesto as a rehabilitation of desire in its multiple forms and as a critique of sexual moralism, including the century-long tradition of homophobia. Copies of Valentine's manifesto had been delivered to Lacerba by Palazzeschi.

The manifestos were eventually translated into twenty-three languages. Saint-Point reading her manifestos became a feature of a futurist traveling performance in 1913 that was staged in art galleries, cabarets, and clubs throughout Europe, including London, Berlin, and Rotterdam. By the end of the year, however, Valentine had already cut herself off from futurism to pursue her own avant-garde dance project, Métachorie.

Many of the ideas in Valentine's manifestos were derived directly from her previous work, though the rhetoric and form of the manifesto make their impact more powerful and less nuanced. Anticipating a theme that was later to gain wide currency in contemporary feminist theory, Valentine argued against biological essentialism, claiming that to divide humanity along gender lines on the basis of sexual difference is absurd inasmuch as it is neither an absolute nor a valid basis for differentiating among human beings. Not only do men and women alike partake of the masculine and the feminine in varying degrees across a spectrum of sexual roles and attitudes, but, according to Valentine, the feminine and the masculine themselves are relative categories, culturally and historically variable and subject to change, rather than a fixed binary opposition. For Valentine (as for, much later, Julia Kristeva) it is not the biological sex of a person, but the subject position he or she takes within a given cultural and social context that defines his or her identity and transgressive potential.

If women at present happen to be trapped by the traditional patriarchal roles and values denounced by Marinetti, it is not because these roles belong to them naturally or by instinct, Valentine argues in "Le manifeste 
de la femme futuriste," for women can also be virile warriors: "guerrières qui combattent plus férocement que les mâles" (Manifeste 16). Valentine, however, sees the potential role of futurist women as that of undermining the present social order precisely from within the key institutions of patriarchy. Within the family, she argues, woman should become the sole ruler of her children, and only as long as the children need her protection. She should, furthermore, abandon those qualities of passivity and patience that have traditionally been assigned to her as the angel of the hearth. The role of wife should be abolished altogether, freeing woman from her subjection to man.

One of the most striking contentions of Valentine's two manifestos, although couched in a rather melodramatic and hyperbolic language designed (in true futurist fashion) to shock the audience, was the notion that the libido or life-instinct is a sexually unmarked instinctual force active in both men and women, whose potential violence is also common to both sexes. Valentine cites the Amazons, the Biblical Judith, Cleopatra, Messalina, and Charlotte Corday - among others-as examples of female warriors capable of fighting more bravely than men (16). Furthermore Valentine, like Freud, argues that all human beings are essentially bisexual, and that "femininity" and "masculinity" are not "natural" or "proper" to either sex: both man and woman can partake of masculinity and femininity in different degrees (14).

Like Marinetti (and Freud to some extent) Valentine associates virility with war, conflict and aggression, and femininity with peace, mediation and non-violence (as well as intuition and imagination). She denies, however, that women are naturally, "by instinct" wise, peaceful, and "good" (17), thus implicitly rejecting the notion that women are inherently "feminine." This is the core of her objections to Marinetti, who in his work had appeared to conflate women and the feminine. Furthermore, unlike Marinetti, she judges that both individuals and social groups in which masculinity predominates are unproductive and brutish. The present moment in her view sees an excess not of masculinity, however, but of femininity; Valentine thus concurs with Marinetti as well as Nietzsche, for whom femininity was also a marker of all that was deprecable in the fin-de-siècle.

A compensatory plunge into brutal force, according to Valentine, is what is needed in this excessively effeminate age. Yet no revolution can be accomplished without women; indeed, according to Valentine, women are potentially the most powerful agents of revolution. Within this revolutionary perspective, the suffragist feminist movement appears counterproductive. As is the case with Julia Kristeva's notorious skepticism vis-à-vis 
women's rights movements, Valentine was a feminist who did not believe in feminism as a political movement. According to Valentine, giving women the vote would normalize them and defuse their revolutionary potential, not, as Marinetti thought, produce a welcome disorder and destruction in the European parliamentary systems. Like Marinetti, Valentine is against the bourgeois family as the primary cell of conservatism and feels that sexual union should be separate from the rearing of children, who belong solely to the mother.

But it was the truly shocking last section of Valentine's manifesto that made her a precursor of the likes of Artaud and Bataille as well as that of more recent (and literal-minded) performance artists, such as Orlan and Gina Pane (though contemporary women's performances seem to tend to use violence almost exclusively masochistically). Here Valentine builds on her initial idea of woman as a potential warrior, taking it to an extreme that goes well beyond Joan of Arc and Charlotte Corday, women who were, after all, national heroines. War in Valentine's vision becomes a pleasurable form of extreme sadism, sublime because violently transgressive. She invokes mutilation of the enemy (a clear metaphor for castration) as a pleasurable and sublime act. Although Valentine, like some prominent contemporary Italian, French, and American feminists, recognizes maternity as an essential feature of womanhood, she is far from any sentimental vision of the maternal as inherently non-violent. On the contrary, for her procreation is yet another extreme act, for the life of the children is destined to be sacrificed in the carnage of war.

Given Marinetti's and the futurists' blatant misogyny, it has often appeared surprising and paradoxical that Valentine should have been attracted by futurism, that futurism should have enjoyed a notable success among women, and that later a considerable number of women intellectuals should have wished to become futurists themselves. To attribute this phenomenon to a form of collective female masochism, however, is both disingenuous and overly simplistic. Indeed, at least in the case of Valentine de Saint-Point, the opposite impulse was blatantly at work. She was attracted by the violence promised by futurism and she wished to partake in it not as an object but as a subject. This shamelessly "masculine," active and aggressive impulse (which placed Valentine de Saint-Point in a position similar to that of certain Greek heroines-Medea, Elektra, Clitemnestrawhom she admired) appears to be precisely what still makes Valentine disturbing and unacceptable to some of her critics.

What distinguishes Valentine's position most sharply from that of Marinetti, and the reason of the controversy that led her to write the sec- 
ond manifesto, is her re-evaluation of female eros and sexual desire, which she calls luxure. The word, as we have seen, is reminiscent of Dante's lussuria as evoked by Canudo, but it also alludes to woman's sensual luxe, the fetishistic and narcissistic desire for expensive and beautiful ornamentation of the body.

In Valentine's rather Reichian view, however, luxure and the eroticism of the body are not associated principally with woman and the female body. Instead, luxure is the most potentially transgressive force in human existence for both men and women, who must become conscious of its psychology and value while freeing themselves from all forms of sentimental mystification and moralism. Female sexuality in particular does not have to be passive, hidden, or repressed, she argues in "Manifeste futuriste de la luxure." It can on the contrary be a source of strength and creative inspiration for women. In opposition to all the fin-de-siècle and belle époque stereotypes of female sexuality as primitive, uncontrollable, dangerous and animalistic, Valentine's notion of luxure as a creative force constitutes a significant reappropriation of female desire by a woman. Of all of Valentine's ideas, this was probably the most influential. It resonated deeply within futurism and we find variations of it in the work of Mina Loy, Enif Robert and Benedetta, among others.

Crucial in Valentine's argument is the notion that the traditional body/mind or body/spirit dichotomy which permeated traditional as well as much avant-garde art is untenable. The search for the unknown can be undertaken through the body (24). Indeed, there is an epistemological and spiritual dimension of the body, and of eroticism in its extreme forms, that has been ignored for too long. For Valentine, the flesh can be creative just like the spirit can, and neither is superior to the other. This argument's subtext is clearly the alignment of the body with the "inferior" feminine realm, in opposition to the superiority of male spirituality and creativity-an argument that dates back to Plato and subtends his praise of spiritual male homosexual love as superior to heterosexual love. Valentine, echoing Nietzsche, criticizes the Christian devaluation of the sensual body, its turning of luxure into a vice and a sin, and calls for an end to the repression of desire between two bodies, "whatever their sex" (27).

But it is not enough to ban all sentimentalism and pruderic (as advocated by Marinetti): luxure must be reflected on, it must become the domain of the intellect as well as the flesh, and even be shaped like a work of art, exalting the individuals' reciprocal sensibility and sensuality (28). Clearly, we are far from Marinetti's "contatti rapidi e disinvolti" as well as from his statement in "Against Love and Parliamentarism" (1910) that lus- 
suria was as unnecessary as sentimentalism, coitus being needed only for the reproduction of the species. To Valentine, luxure must be as daring and experimental, as complex, dynamic, and visionary as avant-garde art itself. Like avant-garde art, luxure in this sense is the work of a visionary élite that promises to be liberatory for humanity as a whole. In its ever-renewed, perennially unappeased, and thus future-oriented movement-the movement of desire itself-Valentine's luxure becomes indeed a metaphor for the dynamic, violent spirit of the avant-garde ("la perpétuelle bataille jaimais gagnée") if not of futurism per se.

The ultimate difference between Valentine and Marinetti is that the ideal futurist hero(ine) for Valentine is neither a man nor a woman, but an altogether new being who would challenge the hegemonic gender codes of the fin-de-siècle and the belle époque, as well as Marinetti's own misogynistic rhetoric. Just as Valentine was unable fully to accept and embrace futurism's literalization of war and the actual celebration of the carnage in which Canudo also took part, Marinetti was unable to accept the conceptual, symbolic violence of Valentine's idea of the androgyne, or female warrior.

Contrary to Monique Wittig (in whose 1969 utopian novel Les guérillères one can see substantial affinities not only with Valentine's ideas on women, but also with certain futurist narrative strategies) Valentine does not offer a militant exaltation of the supremacy of women. Valentine's notion of an exceptional being echos rather the classical topos of the androgyne which appeared often in her poetic texts, ${ }^{25}$ and also fascinated Sibilla Aleramo and other women modernists and avant-gardists. Virginia Woolf's 1929 A Room of One's Own helped to make the androgyne one of the central concepts of the contemporary feminist debate on sexual difference. In France, the mythic figure of the androgyne emerged in the work of another, later lover of Nietzsche, the feminist theorist Luce Irigaray.

Like Virginia Woolf, Valentine de Saint-Point was interested in a new kind of "superior" subject with an emotional and intellectual range that included both male and female elements. And like Virginia Woolf, Valentine's deconstruction of sexual identity-despite its authentically feminist implications - prevented her from sympathizing with the reformist political position in the bourgeois feminist struggles of her day. However, Valentine's androgynous ideal is not (as Woolf's might have been) a way of repressing her ambition, and her condition as woman. ${ }^{26}$ Nor is it certainly a way, as in Carolyn Heilbrun's work, to envision the possibility to free men from the compulsion to violence.

Valentine's androgynous ideal, which became important in her theory and practice of dance, was antithetical to the prevalent misogynist evolu- 
tionist scenario and specifically to Darwin's notion that an androgynous being might have been a remote primitive progenitor of the whole invertebrate kingdom. Darwin's (and Weininger's) view was that the evolutionary division of the sexes led to the "natural" and progressive division of responsibilities whereby men acquired the superior evolutionary task of production and creativity, while women were confined to the more primitive and repetitive function of reproduction. This vision was also embraced by fascism, which considered all forms of crossed gender roles, androgyny or bisexuality, to be dangerous and sick. Valentine, on the contrary, however mindful of the classical and romantic myth, turns the androgyne into a future-oriented ideal. Her androgyne is neither a hybrid, primordial being split into male and female, nor (as in the romantic version), the primary male essence "completed" by the female essence. ${ }^{27}$ Hers is a being ("Être") in whom-whatever his or her sex-the power and strength of both masculinity and femininity are combined in an unfixed, constantly (and historically) shifting dynamism. As such, the androgyne to Valentine, like Irigaray, can only be a state of mind, a way of thinking, feeling and constructing the reciprocal dialectic of body and mind, flesh and spirit.

\section{Meta-dance, Abstraction, Androgyny and Aridity}

The dance spectacle that she named Métachorie (literally "Beyond the chorus") became the principal vehicle for Valentine's vision of the modernist androgyne. In her manifesto, "La Métachorie," Valentine explains that she takes "chorus" as a synonym of dance; thus hers is really a meta-dance. It goes beyond dance as traditionally conceived and, at the same time, it is a critical reflection on dance through dance. An early commentator, Henri Le Bret, further explains that Métachorie also defies the spirit of the Greek chorus, which was to express the crushing inevitability of Fate (30). One of the apparent inevitabilities that Valentine seeks to defy is precisely that of an essential sexual difference between man and woman. Although she is a female performer, she rejects the traditional association between the dancing body and feeling, passion, intuition, the heart, nature, and spontaneity as embodied especially by Isadora Duncan, who had famously danced naked on the stage, seeking to incarnate the eternal essence of woman. ${ }^{28}$ In Métachorie, Valentine seeks to reject the mythical spontaneity, naturalness and femininity of eroticism, taking eroticism itself to a higher level of abstraction where the traditional borders between body and mind, and female and male, are called into question.

Valentine also rejects mimesis, imitation and pantomime (however stylized) and any movement that might suggest a realistic imitation or copy 
of life or nature. Loïe Fuller, probably the most famous dancer of the belle époque, excelled in the art of imitating flowers, butterflies, and moths, partly through the help of vast quantities of fabric and gauze in her stunning billowing costumes. Marinetti and prominent futurists such as Balla and Severini admired her innovative use of light, which expanded rhythmical movement and the dance's dynamism beyond the natural confines of the body. Her diaphanous costumes however, tended to reveal rather than hide the body, creating the effect of a fusion of the sensuous female form with the natural being she imitated. In positivist culture of course, woman was supposed to be naturally imitative as well as closer to nature; hence her inferiority in comparison to man, who was thought to be more rational and abstract. It is an opposition that keeps resurfacing stubbornly even within the avant-garde, and especially in the work of abstractionists such as Mondrian and Kandinsky.

In contrast to both Duncan and Fuller, Valentine's theory requires that the body and face of the dancer be veiled. The function of the veil (or mask) is not only to de-personalize and de-naturalize the body, but also to de-feminize it at times, making it more ambiguous and abstract. The details of the face and of the body must remain hidden so that only the essential lines of the body's movement and rhythm are visible. Veiling or masking the face in particular prevents the illusion of being able to decipher the dance on the basis of visual expression, the "natural" reflection of feeling and emotion in the face. In "La Métachorie," Valentine is also critical of classical ballet and of the way the ballerina, in her esthetic positions, is supposed to recall and represent a classical vision of beauty. In classical ballet, Valentine feels, movement is only a connecting link between beautiful positions, while she wishes to make movement itself significant.

In a formulation that shows the futurist influence on her, she not only stresses the essential importance of movement for modern art, but emphasizes also the need for precision. (Violence and precision were the key components of the quintessential futurist art of the manifesto, as Marjorie Perloff has shown). One cannot dance intuitively and rhythmically, following the spontaneous lead of the body as it follows music. Nor should dance be subordinated or accessory to music. Dance must be an exactly calculated and choreographed, disciplined set of movements that embody an idea or vision. In this case, such an idea or vision is not a Platonic essence, but an interpretation of a series of poems written by Valentine herself. The dance does not illustrate the poem in any way, however, but rather offers through movement an interpretation of its meaning. The dance is the "plastic expression of the spirit and of the movement of the psyche" 
that subtend each poem (53). The dance thus becomes a kind of abstract, interpretive and figural writing that coincides with the poem's reading.

The exactly calculated and choreographed dance is in fact only one element of the spectacle of Métachorie, that includes the reading of poems from off-stage by an actor (a kind of disembodied, abstract voice) music, and light projections of colours and geometrical shapes. Valentine envisions Métachorie as a synthesis of music, poetry, dance, and geometry. Geometry for her stands also, partly but not exclusively through perspective, as a figure for architecture, painting, and sculpture. Her statement on the centrality of geometry brings to mind the role of sacred geometry in certain forms of abstraction, for example in Mondrian (but also in futurism, as for example in Balla) where it is connected to theosophical ideas. Such an esoteric connection is also implicit in Valentine, though without the essentialist underpinnings in terms of gender that are present in Mondrian. ${ }^{29}$ The basic abstract geometrical shapes drawn by the moving body are the line, the square, the circle, the cone, and the spiral, each with its rich background of esoteric connotations. For Valentine, the face and body must be veiled, and sexuality spiritualized and shaped by the intellect. ${ }^{30}$ Foreshadowing her interest in Islam, Valentine's veiled face and body and the geometric patterning of her choreographies suggest the traditional Islamic rejection of the figure and of mimesis in favour of refined and intricate abstraction.

The reactions to Valentine's first dance performance, which took place on 20 December 1913 at the Comédie des Champs Elysées and was introduced by a reading of her manifesto by a male actor, were contradictory. Some felt that Valentine's dance had an excessively athletic, masculine muscular quality, others that the dancer seemed naked under her feminine diaphanous tulles. ${ }^{31}$ Günter Berghaus perceptively remarks that the second impression was probably an effect of the lighting. However, what the reviews seem to point to is really the gender ambiguity of the performance, as well as its unusual complexity, and the difficulty involved in deciphering it.

The performance was articulated in four interconnected parts, each of which corresponded to a series of Valentine's own poems that were read offstage by a male actor: poems of love, atmospheric poems, pantheistic poems, and war poems. Each was accompanied by a different music: Florent Schmitt's "La guerre dans les airs," Debussy's "Demoiselle élue," Satie's "Les pantins dansent" and "Hymne au soleil," and, probably, the futurist Balilla Pratella's "La guerra." (Pratella's music had been commissioned by Marinetti in 1912 specifically to accompany Valentine's war poem). ${ }^{32}$ 
Valentine's costumes for the first performance were designed by Vivian du Mas and must therefore be seen in a theosophical context as well. They were of three different kinds: Greek-like robes and drapings with flowing and diaphanous multi-colored tulles, simple, almost severe orientalist costumes, and martial-looking costumes with Merovingian details such as the plumed helmet mentioned by Marinetti in the highly critical "Manifesto della danza futurista" of 8 July 1917. While the most clearly androgynous costume was the last, which made Valentine appear like a phantasmagorical warrior, the series of dances was apparently meant to be seen as a conflicting and dynamic whole. Each dance evokes a possible gender position as well as a historical moment, in a homage to both the national past and Valentine's personal past-however modernistically reinterpreted-that could only be anathema to futurism.

In his 1917 critique of Valentine's Métachorie, Marinetti denounced the "aridity" of Valentine's excessively abstract, cold, and cerebral style and objected to the dancer's wearing of an oriental veil and a warrior-like, plumed helmet (Teoria 146-147). Such a critique is effectively equivalent to accusing Valentine of being unfeminine. Aridity (a term also used by Locke 74) 33 is but another word for frigidity here, the inability to feel and give pleasure as a woman; and the plumed helmet represents yet another usurpation of the phallus. As for the oriental veil, its symbolism is doubly heretical: on the one hand it hides the feminine body that futurism wishes to control and even expropriate, making it unavailable and abstract, on the other hand the veil evokes the very same decadent and orientalist feminine sensuality that futurism wished to eradicate and supplant. For Valentine, the veil represents a personal, symbolic connection with Lamartine's Orient, even as the Orient had increasingly become for many nationalists - for example Barrès - a sign of everything that was dangerously corrupting and alien to the spiritual health of France. Later in her life, Valentine would actually experience the political complexities of veiling in a colonial and Muslim context. Most heretical from a futurist viewpoint, however, is the copresence of those two symbols - the masculine plumed helmet and the feminine oriental veil-and the symbolic oscillation between the two. It is this androgynous oscillation that makes Valentine unacceptable to Marinetti.

While Marinetti initially welcomed Valentine and was even influenced by her in some ways, he was not yet ready for a female warrior. As feminized and androgynous as some futurist heroes and images are-including the maternal Mafarka and Boccioni's pregnant "Materia"-and as important a role the "feminine" body, matter, and intuition had for futurism in 
charting its transgressive course, the figure of the abstracted, "masculinized," strong erotic woman still remained excessive and intolerable.

For Marinetti, futurist dance had to glorify male heroism and man's symbiosis with the machines of speed and war. Conventional notions of choreography and all harmonious motions traditionally considered to evoke beauty, seductiveness, eroticism, and sentiments in dance and ballet were to be abolished and replaced by a new kind of anti-esthetic and asexual performance. Unlike Métachorie, futurist dance was to be not abstract, but rather representational and mimetic. ${ }^{34}$

\section{Goodbye to All That}

During the war, Valentine worked for the Red Cross. She also taught her theory and practice of dance to a small group of male students that was soon called to war and devastated by casualties. It was an experience that led to a radical change of perspective, making her, unlike Canudo, very critical of the war. Although she continued to see in the unavoidable violence of war a kind of terrible and creative beauty (thus still subscribing to an essential part of futurist esthetics), she increasingly came to consider the war a plot fomented by greed and hate. She felt that the individual had been reduced from human being to mere instrument. The act of veiling or masking the face in Métachorie thus took on an added significance for Valentine because, as she told Djuna Barnes, "it is the face and the words that issue from the mouth that make all the wars and all the racial disputes. Covered, nothing would stand in the way of the symbolic beauty of the individual conception of life" (Barnes 230). The interview with Djuna Barnes came out in April 1917, only a few months before the publication of Marinetti's resentful "Manifesto of Futurist Dance." Valentine's performance of Métachorie (her last) at the Metropolitan Opera in New York on the very day of the United States' entrance into the war was actually a farewell of sorts to her old self. 35 Valentine spent the remainder of the war in Morocco and once again she began studying theosophy seriously. At the age of forty-two she converted to Islam, adopting yet another name: Rawhiyya Noureddine.

Most critics have interpreted Valentine's conversion and her subsequent move to Egypt in 1924 as a defeatist "dropping out" of the civilized world. 36 Others have seen it as a decidedly reactionary and anti-feminist turn in her life (Bentivoglio 15). As Zouari has shown, however, after the war Valentine actually first moved to Corsica, where she started an association, the "Collège des Elites," to promote the joint efforts of cultural elites in the West and the Orient to foster a spiritual rebirth and a common, 
cooperative Mediterranean culture based on fraternity rather than exploitation and materialism. This valiant five-year effort collapsed in the face of scepticism, prejudice, and reciprocal suspicion that divided Muslims from non-Muslims. Even then, Valentine did not give up, but chose to direct her energy elsewhere.

Approaching fifty, Valentine moved to Cairo with Jeanne Canudo and Vivian du Mas. The two women worked as journalists and took part in discussions with the Egyptian feminist union (EFU), a diverse group of Westoriented Arabic and European women founded in 1924 by Huda Shaarawi, a highly-educated, charismatic upper-class woman who spoke French as well as Arabic. Seeking to combine European and Islamic feminism, Shaarawi traveled to international feminist conferences (including the 1923 meeting of the International Alliance for Women in Rome) and, like Valentine, was a supporter of Egyptian nationalism and later panArabism. Shaarawi had been brought up in a harem, yet she argued that Islam granted women equal rights and that the Koran had been misinterpreted. Upon her return from the Rome conference she caused an uproar by appearing unveiled. Due to the ambiguous symbolic value of the veil, however, the EFU did not make unveiling a feminist issue (Shaarawi 3544). Veiling (a practice shared by many Jewish, Christian and Islamic women in the urban centres of early twentieth-century Egypt) was in fact almost a female status symbol connected, like the harem and other means of female privacy and spatial seclusion, more to wealth and class than to religion (rural women went unveiled and poor women wore the veil only to go out). Veiling was indeed not required by the Koran, yet in European colonial rhetoric it was widely associated with Islam and taken as a sign of its inferiority and barbarism. ${ }^{37}$ Female self-veiling, practiced by Valentine herself, could thus be construed as an anti-colonial and paradoxically feminist gesture.

Valentine became increasingly sceptical of the Western (and specifically French) orientation of Egyptian feminism, which she found too conservative. She argued that the feminist movement in France was a failure because, in contrast to Germany and England (where suffragism had been far more radical and violent), women had been unable to gain the vote. She was ostracized by the moderate EFU because she openly advocated an alternative, Islamic model. In seeking modernization, Valentine felt, Islamic women should not mimic the French, for this would only lead to defeat and to the loss of their traditional identities and backgrounds. ${ }^{38}$

Valentine's position in Cairo was made more difficult by her unconventional private life. Her lover, Fouad Nared (a poet and journalist who 
was the son of a British diplomat) was considerably younger than she was. Even more worrisome to the colonial elite, however, was Valentine's strange ménage with a man and a woman, Vivian du Mas and Jeanne Canudo, and their mysterious theosophic dealings.

In the mid-to-late 1920s, Valentine wrote consistently in support of the "Egypt for the Egyptians" movement and pan-Arab nationalism in her journal Le Phoenix, subtitled "Organe de la Renaissance Orientale." The title of the journal is doubly significant. In alluding to the mythical bird reborn from the ashes of its former self, it points to the imminent metamorphosis and rebirth of the colonial territories. At the same time, it evokes Valentine's own capacity for intellectual rebirth and metamorphosis, and her interest in androgyny (the phoenix, a key symbol of theosophy, was both male and female). The journal was read especially in Syria and Lebanon, where it was often censored. With Jeanne Canudo and du Mas, Valentine founded a "Circle idéiste," which promoted children's literacy and a pedagogy based on theosophic principles. At the circle, which was open to Syrian nationalists, she lectured on the bankruptcy of Western civilization and the faults of European colonialism, bitterly criticizing the French atrocities in Syria and the bloody repression of the anti-French Druze revolt of 1925-1927. Accused of disloyalty by the French legation, Jeanne Canudo and du Mas were expelled from Cairo and returned to live in France. Only Valentine was allowed to remain, probably to spare an embarrassment to her ex-husband, the minister Charles Dumont.

In Cairo in the early 1930s Valentine met one last time with Marinetti, who was traveling through his native Egypt with his wife Benedetta. A reception in honour of Marinetti was organized by the Egyptian futurist of Italian and Austrian descent Nelson Morpurgo, who invited Valentine. In an interview, many years later, Morpurgo-who was one of the most prominent lawyers in the Italian colony in Cairo-recalled Valentine dressed and made up in an outrageous, incongruous way that looked to him like a grotesque masquerade (and was the antithesis of Benedetta's understated, elegant style). Apparently though, the older woman was still fascinating and had by then assumed such a mythic status as part of futurism's heroic and erotic past that Benedetta resented her presence and, losing her usual poise, made her feelings clear to the host and to her husband. ${ }^{39}$

Valentine's last known published work was a collection of poems, $\mathrm{La}$ Caravane des chimères (1934). Towards the end of her long nomadic life, Valentine lived in rue Imad Eddine in Cairo, occasionally practicing acupuncture and "radiesthésie." In Cairo society she was rumored to be (like the femme fatale in the futurist film Thais) a magician with occult 
powers. Having spent all her money (most of which ironically appears to have come from the divorce settlement with Dumont) on Le Phoenix, Valentine became disillusioned with politics and withdrew into a contemplative, ascetic life until her death in 1953, the year of the declaration of Egyptian independence from colonial rule.

University of California, Los Angeles

\section{NOTES}

${ }^{1}$ See for example Macciocchi 121, Blum 105-106, Spackman 37-40, Bentivoglio 14-15 and Lyon 149-150. Valentine's manifestos have been republished and can be found in de Saint-Point, Manifeste.

${ }^{2}$ See for example Locke. For a more balanced view, see Franko.

${ }^{3}$ Zouari wrote her dissertation on Valentine de Saint-Point, on which she based a biography written in the form of a documentary novel, La Caravane des chimeres. Zouari is also the author of the essay Pour en finir avec Shaharazade, a feminist critique of Orientalism. Zouari's interest in Valentine stems from Valentine's own interest from the mid-1920s in the feminist and nationalist movements in Egypt. The biography by Richard de la Fuente also offers a useful account of Valentine's years in Egypt.

${ }^{4}$ Lamartine (1790-1869) was one of the most famous French romantic poets, intellectuals, travelers, and statesmen, author of the autobiographical Méditations poétiques (1820) and of the hugely popular Harmonies poétiques et religieuses (1830). After a journey to Egypt, Syria and Morocco chronicled in Voyage en Orient (1835), he was elected to the chamber of deputies and wrote celebrated essays about universal peace and the freedom of the press. His History of the Girondists (1847) foreshadowed the 1848 revolution. That year, he gained a post in the republican government as minister of foreign affairs, but his political activities ceased entirely after the coup d'état by Napoleon III. Valentine commemorated Lamartine's role in 1848 in an early poem, "Lamartine," in Poèmes d'orgueil 107-109.

${ }^{5}$ This is the spelling used by Zouari, though a variety of other spellings are adopted by different scholars.

${ }^{6}$ See especially Nomadic Subjects. Neither here nor in the later Metamorphoses, however, does Braidotti seem to be aware of the ways in which the theme of nomadic, transformative subjectivity emerges in the work of avant-garde women artists such as Valentine and (in a different way) Rosa Rosà, author of the futurist novel Una donna con tre anime (1919).

${ }^{7}$ Divorce had been reintroduced in France in 1884, but there was no mutual consent clause. By law, the husband's adultery was punished with a fine, while the punishment for women was imprisonment. Furthermore, women were still sub- 
ject to marital authorization. They gained legal control of their own earnings and finances, including divorce settlements, in 1907.

${ }^{8}$ See Feminisms and Waelti-Walters, Feminist Novelists. The latter includes a useful discussion of Valentine's novels.

${ }^{9}$ On sartorial female fetishism, see Apter. See also de Lauretis 273-274. Unlike Apter, who regards female fetishism as compensatory for any kind of deeply-felt loss, de Lauretis argues that female fetishism and masquerade are inseparable from the specifically sexual castration complex.

${ }^{10}$ Later yet though, in Una sensibilità italiana nata in Egitto, Marinetti nostalgically recalled Valentine's elegance at the time of the 1912 performance of her "Manifeste futuriste de la luxure," describing Valentine's luxurious real pearls, the sumptuous elegance of her silver shoe (fetishistically evoked in the singular) and "the most beautiful foot in the world"(288).

${ }^{11}$ The lecture, entitled "L'CEuvre du sculpteur Rodin," was delivered at the Université Populaire on 25 January. See Lista 56.

${ }^{12}$ See for example Cottington 191. Dotoli's work on Canudo, somewhat apologetic in tone, is very useful; see especially Lo scrittore totale. See also Canudo.

${ }^{13}$ Valentine lectured on contemporary literature and women at the Maison des Etudiants in Paris on 25 May 1911, and on women in the theatre at the Université Populaire du Fabourg Saint-Antoine in Paris on 2 December 1912.

${ }^{14}$ See Guglielminetti.

${ }^{15}$ See Locke's reading (80-81) of the scene in L'Orbe pâle in which the female protagonist dreams of killing with her sword an Arab man who, like all men of all races and all religions, presumes to possess her sexually.

${ }^{16}$ On the development of Freud's notion of penis envy, see Laplanche and Pontalis 303-304.

${ }^{17}$ D'Annunzio's tragedy was a flop on stage mainly as a result of an inadequate cast and production, but later it was made into two successful films by Eduardo Bencivenga in 1912 and by Gabriellino D'Annunzio in 1921.

${ }^{18}$ On the psychoanalytic dimensions of "perverse desire" and the limits of the notion of the "masculinity complex" to define both lesbians (and, I would add, certain heterosexual women), see de Lauretis.

${ }^{19}$ Besides La Nave, Canudo translated into French the tragedy Fedra, and wrote screen adaptations for several of D'Annunzio's plays and novels. D'Annunzio was unhappy with both the translations and the screen adaptations however, perhaps because he felt that Canudo was infringing on his territory and taking too large a role in the Latin/Mediterranean revival movement.

${ }^{20}$ See the front-page editorial, "Gauche libérale," by Divoire.

${ }^{21}$ For Marinetti's account of the performance and the various reactions, see La grande Milano 80-84 and 279-287.

${ }^{22}$ In 1910 in Naples Marinetti gave a speech entitled "Bellezza e necessità della violenza" that is clearly and directly inspired by Sorel. 
${ }^{23}$ On the conflictual figurations of the mother in Mafarka, see Spackman 52-76.

${ }^{24}$ See Cannistraro and Sullivan 101-102, where it is reported that Diego Rivera believed Valentine de Saint-Point to be having a lesbian affair with Margherita Sarfatti. For a description of Valentine's performance and the ensuing chaos, see Severini 117-118.

${ }^{25}$ See for example the poem "Être." On the theme of the androgyne in Valentine, see Dotoli 173-175. Canudo was also fascinated by the theme of the androgyne and published a series of sonnets inspired by it in Poesia (1906-07).

${ }^{26}$ This critique of Woolf appears in Showalter 264.

${ }^{27}$ On the romantic version of the androgyne, see Weil 63-72.

${ }^{28}$ For a comparison between Isadora Duncan and Valentine, see Franko 21-24.

${ }^{29}$ On Mondrian's essentialism, see Cheetman.

${ }^{30}$ Although he initially welcomed them as a form of almost cinematic spectacle, Ricciotto Canudo criticized the commercialism of the Ballets Russes in Montojoie! 7, 16 May 1913. See Cottington 191.

${ }^{31}$ See Berghaus. The article gives an overall account of the reviews.

${ }^{32}$ There is some question as to weather Pratella's music was actually used in this performance, as no reviewer mentions it. See Berghaus 30 and 42.

${ }^{33}$ Locke goes on to conclude in fact that Valentine's work has "no real feminine enjoyment, no female jouissance" (91).

${ }^{34}$ The actual futurist practice of choreography, dance, and performance in the 1920s and 1930s was very rich and complex, and included a variety of brilliant avant-garde experiments with abstraction, "mechanical" ballet, pantomime, and aerial dance that went well beyond the limited parameters of Marinetti's manifesto. For an overview centered on the figure of the famous futurist dancer Giannina Censi, see the essays collected in Giannina Censi.

35 On the Metropolitan opera performance, see Satin.

${ }^{36}$ See for example Dotoli 171: "sconfitta . . lascia l'Europa e va a vivere fra i fumi dell'Oriente, in Egitto, dove morirà nel 1953." In fact, a number of disenchanted French intellectuals converted to Islam and moved to Islamic countries after the First World War. One of them was André Guénon, who was once an acquaintance of Valentine's in Paris and became one of her few friends during her Egyptian period. Guénon, whose complex traditionalist, anti-modernist and occultist thought was coopted by Julius Evola and later by the esoteric fascist movement, died in Cairo in 1951.

${ }^{37}$ For example Lord Cromer, British consul general in Egypt from 1883 to 1907 (and a notorious anti-suffragist at home) often pointed to veiling as a symptom of the degradation of women and the most obvious sign of Islam's inferiority to Western civilization (Ahmed 151).

${ }^{38}$ Even in this, Valentine anticipated aspects of contemporary feminism. For a discussion of Islamic feminism as an alternative to imported European models, see Ahmed. 
${ }^{39}$ The interview is in Lambiase and Nazzaro 112-114. Morpurgo states that the reception took place in 1938, but the most likely year is 1930. Marinetti and Benedetta's trip to Egypt is documented in the series of Marinetti's narrative fragments published in installments by La Gazzetta del Popolo in 1930 and later collected in the volume Il fascino dell'Egitto (1933), now included in Teoria.

\section{WORKS CITED}

Ahmed, Leila. Women and Gender in Islam: Historical Roots of a Modern Debate. New Haven, Yale University, 1992.

Apter, Emily. Feminizing the Fetish: Psychoanalysis and Narrative Obsession in Turnof-the-Century France. Ithaca: Cornell University Press, 1991.

Barnes, Djuna. "Recruiting for Métachorie" (1917) pp. 223-235 in Interviews. Los Angeles: Sun \& Moon Press, 1985.

Bentivoglio, Mirella, "Valentine de Saint-Point." pp. 7-15 in Women Artists of Futurism. Almost Lost to History. Ed. Mirella Bentivoglio and Franca Zoccoli. New York: Midmarch Arts Press, 1997.

Berghaus, Günther. "Dance and the Futurist Woman: The Work of Valentine de Saint-Point (1875-1953).” Dance Research 11 (Autumn 1993): 27-42.

Blum, Cinzia. The Other Modernism. F. T. Marinetti's Futurist Fiction of Power. Berkeley: University of California Press, 1996.

Braidotti, Rosi. Nomadic Subjects. Embodiment and Sexual Difference in Contemporary Feminist Theory. New York: Columbia University Press, 1994. . Metamorphoses. Towards a Materialist Theory of Becoming. Cambridge: Polity Press, 2002.

Canudo, Ricciotto. L'Âme Dantesque. Paris: La Renaissance du Livre, 1922. . "Reflections on the Seventh Art" 1:296-297 in French Film Theory and Criticism: A History/Anthology, 1907-1939. Ed. Richard Abel. Princeton: Princeton University Press, 1988. 2 vols.

Cannistraro, Philip and Brian Sullivan, Il Duce's Other Woman. New York: Morrow, 1993.

Canudo, special issue of Quaderni del Novecento francese. Ed. M. Décaudin. Rome: Bulzoni, 1976.

Cheetman, Mark. The Rhetoric of Purity. Essentialist Theory and the Advent of Abstract Painting. Cambridge: Cambridge University Press, 1991.

Cottington, David. Cubism in the Shadow of War. The Avant-Garde and Politics in Paris 1905-1914. New Haven and London: Yale University Press, 1998.

de Lauretis, Teresa. The Practice of Love. Lesbian Sexuality and Perverse Desire. Bloomington: Indiana University Press, 1994. de Saint-Point, Valentine. "Être." Poesia, second series, 1 (April 1920): 31-33. Manifeste de la femme futuriste, suivi de: Manifeste futuriste de la luxure, Le Théâtre de la femme, La Métachorie. Ed. Giovanni Lista. Paris: Séguier, 1996. 
Poèmes d'orgueil. Paris: Editions de l'Abbaye, 1908.

La Soif et les mirages. Paris: Éditions Figuière, 1912.

Divoire, Fernand. "Gauche Libéral." Montjoie! 3 (14 March 1913).

Dotoli, Giovanni. Lo scrittore totale. Saggi su Ricciotto Canudo. Fasano: Scena Editore, 1986.

Feminisms of the Belle Epoque: A Historical and Literary Anthology. Eds. Jennifer

Waelti-Walters and Steven C. Hause. Lincoln and London: University of Nebraska Press, 1994.

Franko, Mark. Dancing Modernism / Performing Politics. Bloomington: Indiana University Press, 1995.

Giannina Censi: Danzare il futurismo. Exhibirion catalogue, Museo d'Arte Moderna e Contemporanea di Trento e Rovereto. Ed. Elisa Vaccarino. Milan: Electa, 1998.

Guglielminetti, Marziano. Amalia : la rivincita della femmina. Genoa: Costa \& Nolan, 1987.

Lamartine, Alphonse de. Histoire de la Turquie. Vol 2. Paris: Constitionel, 1854.8 vols.

Laplanche J. and J.-B. Pontalis. The Language of Psychoanalysis, trans. Donald Nicholson-Smith. New York: Norton, 1973.

Le Bret, Henri. Essais sur Valentine de Saint-Point. Nice, 1923.

Lista, Giovanni. Futurisme. Manifestes, Proclamations, Documents. Lausanne: L'Age d'Homme, 1973.

Locke, Nancy. "Valentine de Saint-Point and the Fascist Construction of Woman" pp. 73-100 in Fascist Visions: Art and Ideology in France and Italy. Eds. Matthew Affron and Mark Antliff. Princeton, NJ: Princeton University Press, 1997.

Lyon, Janet. Manifestoes. Provocations of the Modern. Ithaca, NY: Cornell U.P., 1999.

Macciocchi, Maria Antonietta. La donna nera. Consenso femminile e fascismo. Milan: Feltrinelli, 1976.

Marinetti e i futuristi. Ed. S. Lambiase and G. B. Nazzaro. Milan: Garzanti, 1978. Marinetti, Filippo Tommaso. La grande Milano Tradizionale e futurista. Una sensibilità italiana nata in Egitto. Ed. Luciano de Maria. Milan: Mondadori, 1969. - Le Roi Bombance. Paris: Mercure de France, 1905.

Teoria e invenzione futurista. Ed. Luciano De Maria. Milan: Mondadori,

1968.

Nietzsche, Friedrich. The Gay Science. Trans. Walter Kaufmann. New York: Vintage, 1974.

1978.

Perloff, Marjorie. The Futurist Moment: Avant-Garde, Avant Guerre, and the Language of Rupture. Chicago and London: Chicago University Press, 1986.

Richard de la Fuente, Véronique. Valentine de Saint-Point (1875-1953). Une poétesse dans l'avant-garde futuriste et méditerranéiste. Céret: Éditions des Albères, 2003. 
Riviere, Joan. "Womanliness as Masquerade" pp. 35-44 in Formations of Fantasy. Eds. Victor Burgin, James Donald, Cora Kaplan. London: Methuen, 1986.

Satin, Leslie. "Valentine de Saint-Point." Dance Research Journal 22 (Spring 1990): 1-12.

Severini, Gino. La vita di un pittore (1946). Milan: Feltrinelli, 1983.

Shaarawi, Huda. Harem Years: The Memoirs of an Egyptian Feminist (1879-1924). Trans. and ed. Margot Badran. New York: Feminist Press, 1986. 35-44.

Showalter, Elaine. A Literature of Their Own: British Women Novelists from Bronte to Lessing. Princeton, NJ: Princeton University Press, 1977.

Sorel, Georges. Reflections on violence. Trans. T. E. Hulme and J. Roth. Introduction by A. Shils. Glencoe, IL.: Free Press, 1950.

Spackman, Barbara. Fascist Virilities. Rhetoric, Ideology, and Social Fantasy in Italy. Minneapolis: University of Minnesota Press, 1996.

Waelti-Walters, Jennifer. Feminist Novelists of the Belle Epoque: Love as a Lifestyle. Bloomington: Indiana U.P., 1990.

Weil, Kari. Androgyny and the Denial of Difference. Charlottesville: University of Virginia Press, 1992.

Zouari, Fawzia. La Caravane des chimères. Paris: Olivier Orban, 1990. Pour en finir avec Shaharazad. Tunis: Cérès, 1996. - Valentine de Saint-Point: un itinéraire de l'Occident à l'Orient. Paris: Université de Paris III, 1984. 